\title{
Modeling Determinants of Individual Punitiveness in a Late Modern Perspective: Data from Japan
}

\author{
Tomoya Mukai $^{1}$ (D) $\cdot$ Yui Fukushima ${ }^{2} \cdot$ Shigeru Iriyama $^{3} \cdot$ Ikuo Aizawa $^{4}$ \\ Received: 3 July 2020 / Accepted: 14 December 2020 / Published online: 6 January 2021 \\ (C) The Author(s), under exclusive licence to Springer Nature B.V. part of Springer Nature 2021
}

\begin{abstract}
There is a growing trend to both theoretically and empirically explain public punitiveness from a general social theory of late modernity. Yet, research which has tested the generalizability of this perspective regarding societies other than Western ones remains rare. Relying on a theoretical perspective and empirical findings, this study aimed to explore whether the hypothetical model, which assumes that abstract late modern anxieties (economic anxiety and identity anxiety) affect punitiveness via more tangible fears and negative attitudes toward others in terms of fear of crime, xenophobic attitudes, and social dominance orientation (SDO). The study considered whether this model can be applied to Japanese society, which is experiencing drastic social, economic, and political transformations. Accordingly, data from a nationwide Japanese sample was analyzed through structural equation modeling (SEM). The results revealed that all of the hypothesized paths had significant relations, except for a path between xenophobic attitudes and fear of crime, which generally supported the hypothetical model. Moreover, it was shown that all of the variables have a significant total effect on punitiveness. The results were discussed in light of the social circumstances of Japan and recommendations for further international comparative research were made.
\end{abstract}

Keywords Punitiveness $\cdot$ Late modernity $\cdot$ Fear of crime $\cdot$ Xenophobic attitudes $\cdot$ Social dominance orientation $\cdot$ Economic anxiety

Tomoya Mukai

tomoyam2015@gmail.com

1 Graduate Schools for Law and Politics, The University of Tokyo, Tokyo, Japan

2 The Institute of Humanities and Sciences, Nihon University, Tokyo, Japan

3 Graduate School of Sociology, Toyo University, Tokyo, Japan

4 Faculty of Law, Rissho University, Tokyo, Japan 


\section{Background}

As the rise in penal populism (Bottoms 1995) gathered great scholarly and social attention over the last decades, public punitiveness, defined as "support for harsher criminal sanctions and crime policies regardless of the goal behind these activities" (Maruna \& King, 2009, p. 9), has become an enthusiastically researched topic. Although existing literatures on public punitiveness have mainly focused on Western societies (Roberts \& Hough, 2005; Roberts et al., 2003), the problem with public punitiveness is not unique to these societies.

Until the 1990s, Japanese society was reputed as having a significantly low crime rate with a rehabilitative (Braithwaite 1989) and "benevolent" (Foote 1992) criminal justice system; arguably, due to these characteristics, the incarceration rates were relatively low. However, since the late 1990s, Japanese society has experienced a higher crime rate and a series of highprofile crimes such as the Kobe double murder case in July 1997, in which a 14-year-old boy killed two elementary school children and beheaded one of them. Moreover, there was the 1995 sarin gas attack of the Tokyo subway system as well as other related crimes which were committed by the religious cult named Aum Shinrikyo. Reflecting such situations, a survey conducted in 2017 (The Nikkoso Research Foundation for Safe Society 2019) showed that approximately two in five $(38.3 \%)$ of the respondents answered that they were "often" or "sometimes" in fear of being victimized.

"The myth of the collapse of the secure society" resulted from these events which then paved the way for a more punitive criminal justice system (Hamai \& Ellis, 2006, 2008). Such developments - known as genbatsuka (㛜罰化) in Japanese - can be observed in the various fields of the Japanese criminal justice system (Fenwick, 2013; Miyazawa, 2008). The incarceration rate within the population during the 1990 to 2005 period nearly doubled, from 38 to 62 individuals per 100,000 (Ministry of Justice, n.d.); additionally, the upper limit of prison sentences was raised from 20 to 30 years by the Criminal Code amendment in 2004. Moreover, new crime categories were created to punish certain acts such as stalking, which began in 2000, and dangerous driving that resulted in death or injury, which was initiated in 2001.

Penal populism is the widely accepted explanation for these punitive legislations and amendments (Bottoms 1995). Researchers who apply this concept to the Japanese context have suggested that various social and judicial developments linked to penal populismdecentralization of the criminal justice system, increased voice of crime victims, populist politicians and the resulting decrease of trust in experts and academics, transformation of media practice, etc. (Garland, 2001; Pratt, 2006; Simon, 2007) — can be observed in Japan (Fenwick, 2013; Miyazawa, 2008).

In these explanations, public punitiveness is especially relevant to the development of state punitiveness. In his research on penal populism in Japan, Miyazawa (2008) concluded that, as crime became salient in public debate, public demands for harsher punishments and skepticism on an established criminal justice system were repeatedly reported by the mass media. As a result, punitive public opinion came to affect penal policies through populist politicians who wished to represent themselves as "tough on crime."

In line with the explanations based on penal populism, existing models of penal policies also emphasize the importance of public attitudes toward penal policies. Lappi-Seppälä (2012) presents a model which illustrates organizations of structures, political/economic/judicial systems as well as cultures, media culture, and public opinion - especially punitiveness, social and economic security, and fears - that interrelate together to affect an actual policy outcome. 
Similarly, the model shown by Indermaur and Hough (2002) shows that public opinion, along with the news media and presence of special interest groups, functions as both cause and outcome of political decision-making.

\section{Theoretical Background}

Then, what factors play a role in determining the individual differences of punitiveness? Some of the best-known theoretical explanations attribute punitiveness to ontological insecurity (Giddens, 1990, 1991). Ontological insecurity refers to a general sense of insecurity which resulted as the once stabilized modern establishment (e.g., community, family, economic system) have been, in the modernizing process, gradually undermined and replaced with late modern instability (see also Bauman, 2000; Beck, 1986). This process includes a broad range of interrelated social developments such as the destabilization of the labor market (Young, 1999, 2010), consumerization or marketization of society (Bauman, 2005), neoliberalization (Harvey, 2005), globalization (Bauman, 2004), and the decay of community (Putnam, 2000).

Applying this general social theory to punitiveness, Young $(1999,2007)$ suggests that criminals are utilized as the scapegoats for a broad range of anxieties stemming from the process of (late-) modernization. In his view, late modern societies are ones that have experienced the drastic changes in the labor force and the structure of the market. These changes have given rise to - via relative deprivation and economic precariousness - economic insecurities. But, in addition to this, individuals in late modern societies also suffer from ontological insecurity. This is because the transformations in family, work, and communities as well as a rise in pluralism and individualism mold together to result in a lack of embedded biography and life trajectory along with the constant confrontation with a plurality of social worlds and beliefs (Giddens, 1991). Consequently, people's self-identity, when disembedded from their sense of biographical continuity, has become less stable. Young (1999) then argues that in such late modern societies, characterized by its exclusive nature, people are inclined to reaffirm or compensate their social/economic status and their identity by scapegoating deviants for their anxieties or excluding them through formal criminal sanctioning.

Likewise, Bauman $(2000,2005,2008)$ points to the heightened sense of insecurity produced in the development of (late-) modernity. For such insecurity functions in the terrain where an individual cannot control, people seek a more tangible and simplified "solution" instead of working on the root of the profound sense of insecurity (i.e., economic/political/ social structures). Attributing a root cause of insecurity to criminals can be a way to find such a "solution" (Bauman, 2000, pp. 50-51). Using a metaphor of "sewers," he explains this point as follows:

The criminalized margins serve as soi-disant tools of sanitation: the sewers into which the inevitable, but poisonous, effluvia of consumerist seduction are disposed, so that the people who manage to stay in the game of consumerism need not worry about the state of their own health. (Bauman, 2005, pp. 80-81)

Thus, according to the late modern perspective, punitiveness is seen as an "outlet" of unpleasant anxiety that is a result of a wider social transformation.

Although these explanations are ones presented in the context of Western industrialized societies, the social phenomena emphasized in them are ones that many industrialized 
countries have commonly come to face in the last few decades. Notably, Japan is not exempt from this situation. Since the bubble economy burst in the early 1990s and the subsequent transformation of its welfare and labor systems (Estévez-Abe, 2008; Tanaka, 2019; Uzuhashi, 2003), Japan has experienced chronic stagnation for nearly 30 years. Consequently, economic inequality has come to gather great attention (Allison, 2013; Hara, 2007; Kumakura \& Kojima, 2018), especially in the aftermath of the Lehman Brothers bankruptcy in the late 2000s. By reflecting on such a situation, an individual's sense of economic anxiety has also strengthened. A survey conducted in 2018 shows that $40.4 \%$ of its respondents answered that they are worried or anxious about the outlook of their future income and assets (Public Relations Office, Cabinet Office, The Government of Japan 2018).

Simultaneously, there has been an increase in xenophobic feelings and movements toward foreigners, especially toward Chinese, Koreans, and North Koreans with whom Japan has had a long history of ambivalent relations. These conflicts have been pointed out by researchers and organizations (ERD net (Japan NGO Network for the Elimination of Racial Discrimination), 2018; Park, 2017). Shiobara (2020) shows that newspaper articles including the word exclusionism (haigaisyugi; 排外主義) have increased, especially since the early 2010s in the wake of widely-reported events such as territorial conflicts over islands with China and Korea. Moreover, historical debates with Korea have reignited regarding "comfort women" and a demand for compensation as well as an apology for damages inflicted by the former Empire of Japan in World War II. There has also been a rise of Japanese hate speech in the form of street demonstrations as well as posts on the Internet.

A nexus among xenophobia and economic as well as identity anxiety is also pointed out. McCormack and Kawabata (2020) argue that the recent development of xenophobia in Japan is partly due to the erosion of once-stable social establishments such as family, company, and nationality which have functioned as a source of individual economic and identity security. They also imply that the abovementioned late modern perspective (Bauman, 2008; Young, 2007) can be a useful framework to explain these interlinked phenomena.

Thus, considering similar social phenomena have been observed in a Japanese context, it appears to be reasonable to assume that such explanations can be also applied to a Japanese context.

\section{Empirical Studies}

However, these explanations are mainly speculative or theoretical, and empirical research conducted on this perspective remains rare (King \& Maruna, 2009). One remarkable exception of this is Hirtenlehner et al. (2016). Building on the late modern perspective, their study has incorporated variables of economic anxiety, xenophobic attitudes, authoritarian attitudes, fear of crime, and punitiveness into an integrated model. Their model is based on several premises, the first of which is people who are anxious about their economic situations foster authoritarian attitudes in the expectation of improving their situation. Therefore, heightened authoritarian attitudes, along with economic anxiety, strengthen their negative attitudes toward foreigners and immigrants who are likely to be perceived as potential competitors of indigenous people. Then, as this economic anxiety is abstract, people seek a more tangible object onto which they can project their sense of anxiety - and thus, their fear of crime is strengthened. Next, there is a stereotype that crime is often committed by foreigners and immigrants. Accordingly, those who have stronger xenophobic attitudes, which can be defined as a negative attitude toward 
ethnic minorities who are perceived as potential competitors for scarce resources and goods (Hirtenlehner et al., 2016), are more likely to be afraid of crime and support punitive measures toward criminals. Finally, because people who are afraid of crime seek to find protection from victimization, they are more likely to have a higher level of punitiveness.

Their model can also be supported by previous empirical studies that investigated individual paths incorporated in the model. For example, King and Maruna (2009) report that economic anxieties exert positive influence on punitiveness. Regarding the relationship between xenophobic attitudes and punitiveness, Garin (2012) indicates that the preference for a closed country - a concept similar to that of xenophobic attitudes - has a positive effect on the vote for a punitive criminal measure (i.e., lifelong detention initiative). Additionally, authoritarianism has shown to relate positively with punitiveness among 27 EU countries (Ousey \& Unnever, 2012). Moreover, while its concept varies among researchers, as discussed subsequently, various studies have shown that fear of crime has a positive influence on punitiveness (Armborst, 2014; Costelloe et al., 2009; Johnson, 2001).

Hirtenlehner et al. (2016) 653 residents of Linz, Austria, using structural equation modeling (SEM). The analysis yielded good fits with a comparative fit index (CFI) of .953 and a root mean square error of approximation (RMSEA) of .047, thus generally supporting the hypothetical model.

As mentioned above, since the phenomena related to the factors included in the model (Hirtenlehner et al., 2016) are observed and their interrelations are also suggested in Japan, there is a possibility that their model may be generalized to Japan. Thus, Mukai et al. (2019) tested this possibility using a sample of 239 university and professional training college students, with a slight alteration of the model from Hirtenlehner et al. (2016). ${ }^{1}$ However, the results reported by Mukai et al. (2019) did not fully support the model: although general fits of the model fell within an acceptable range $(\mathrm{CFI}=.93, \mathrm{RMSEA}=.06)$, the paths between economic anxiety and xenophobic attitudes, xenophobic attitudes and fear of crime, and fear of crime and punitiveness were not significant $(\beta \mathrm{s}=-.10,-.03, .04 ; p \mathrm{~s}=.29, .75, .63$, respectively), as shown in Fig. 1.

Yet, this result does not necessarily mean the model from Hirtenlehner et al. (2016) cannot be applied to Japanese society as Mukai et al. (2019) had several limitations. First, concerning the fear of crime, which is defined as "an emotional response of dread or anxiety to crime or symbols that a person associates with crime" (Ferraro, 1995, p. 4). In this regard, some researchers have considered the difference between the individual level of the fear of crime and the social level of the fear of crime. The former distinguishes to how much of a degree an individual is afraid of himself/herself being victimized; conversely, the latter is about how much of degree a person is concerned about crime situations at a social level (Arai et al., 2010; Armborst, 2014; Ferraro, 1995). Also, in Japanese literature on punitiveness (Mukai \& Fujino, 2018), two dimensions of punitiveness are identified: the first dimension is the support for harsher punishment and the second one is the support for criminalization. The former deals with support for inflicting harsher punishment on acts which are already deemed punishable; accordingly, the latter concerns the support for punishing undesirable acts (i.e., stalking, dangerous driving, etc.), which previously were not officially criminalized. In light of these

\footnotetext{
${ }^{1}$ Mukai et al. (2019) excluded authoritarian attitudes from their model because its original concept (Adorno et al., 1950) included "authoritarian aggression," which refers to attitudes toward punishing moral transgressors. Therefore, regressing authoritarian attitudes on a conceptually overlapping variable of punitiveness might yield an insignificantly high coefficient.
} 


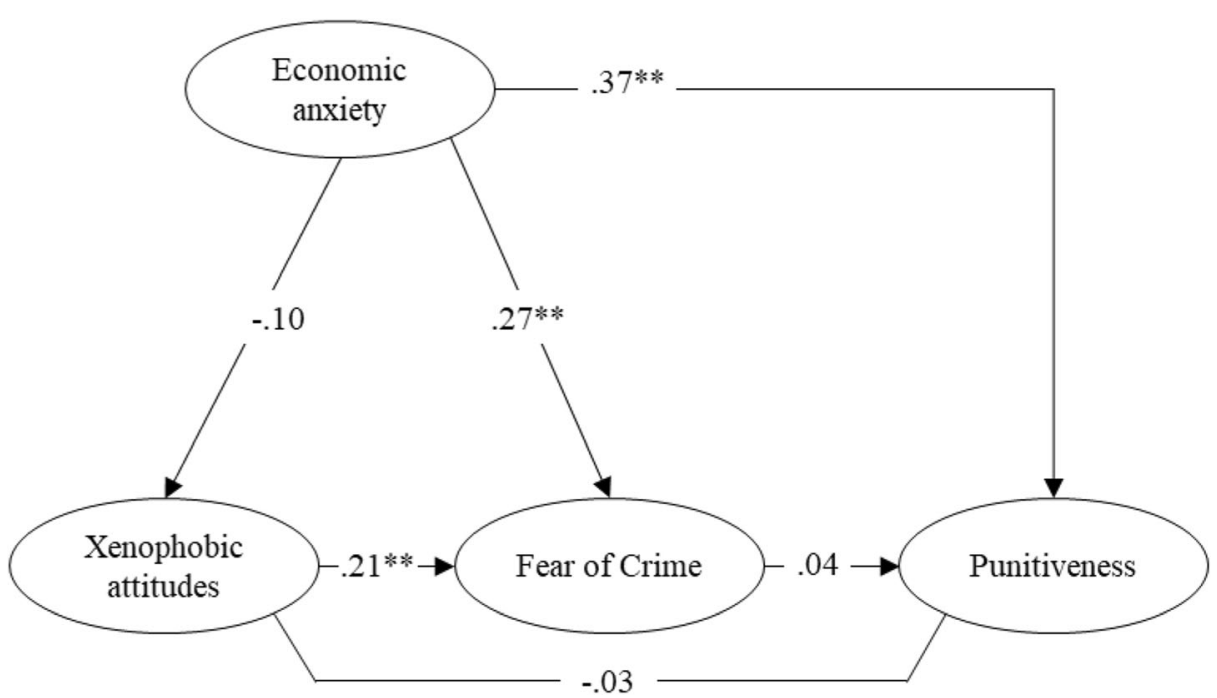

Fig. 1 Path model and its results in Mukai et al. (2019). Values in the figure indicate standardized coefficients. $* * p<.01$. Reprinted and translated from "Modeling determinants of punitiveness: The roles of economic insecurity, fear of crime, and xenophobic attitudes," by T. Mukai et al., 2019, Ryukoku Corrections and Rehabilitation Center Journal, 9, p.73.Copyright 2019 by T. Mukai, Y. Fuskushima, S. Iriyama and I. Aizawa. Reprinted and translated with permission

distinctions, the models by Mukai et al. (2019) and Hirtenlehner et al. (2016) are considered as those that are incorporated at only the individual-level fear of crime and the support for harsher punishment. However, at least in the Japanese context, Mukai \& Matsuki (2020) have shown that different dimensions of punitiveness relate to different levels of the fear of crime. This is with the support for harsher punishment and it relates with the social level of the fear of crime and the support for criminalization with the individual level of the fear of crime. Thus, considering this finding, it is necessary to incorporate the other dimensions and levels of the fear of crime and punitiveness (i.e., support for criminalization and the social level of the fear of crime).

Second, although Mukai et al. (2019) excluded authoritarian attitudes because of the conceptual similarity with punitiveness, it would have been possible to replace this variable with another one. The authoritarian attitude — or authoritarian personality — has been criticized of its conceptual ambiguity and unreliability of scale in measuring its construct (Altemeyer, 1981). From these reasons, more recent research has been adjusted to clarify the concept by focusing on one or a few subconcept(s) of authoritarian attitudes. One such concept is social dominance orientation (SDO), which is defined as "a general attitudinal orientation toward intergroup relations, reflecting whether one generally prefers such relations to be equal, versus hierarchical, that is, ordered along a superior-inferior dimension" (Pratto et al., 1994, p. 742). Conceptual similarity between authoritarian attitudes and SDO have been pointed out by Altemeyer (1998), suggesting that SDO can be seen as an expression of a dominant type of authoritarian attitude. Additionally, SDO has been proved to positively relate with punitiveness in previous studies (Pratto et al., 1994; Sidanius et al., 1994; Sidanius et al., 2006). ${ }^{2}$

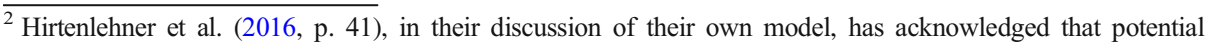
incorporation of SDO.
} 
Third, the original model by Hirtenlehner et al. (2016) and its subsequent model (Mukai et al. 2019) did not include identity anxiety as an independent factor. However, in the abovementioned theoretical explanations (Bauman, 2005; Young, 1999), it has been argued that an individual's identity has become less stable in the development of (late-) modernity, and that this sense of unstable identity has triggered punitiveness. Therefore, to fully test the theoretical explanations, it is appropriate - along with economic insecurity - to incorporate identity anxiety into the model.

In sum, arguments on penal policy developments have pointed out that public punitiveness plays a key role in forming actual penal policies (Miyazawa, 2008). Nevertheless, one model presented to explain public punitiveness (Hirtenlehner et al., 2016) has a rather limited scope in the sense that it has been tested only in the Western context; furthermore, another model presented in Japan (Mukai et al., 2019) failed to fully support the theoretical explanations and the previous model. In this context, the present study aims to both test the existing model's generalizability to the Japanese context and broaden its scope by implementing a few modifications.

The hypothetical model the present study tests is shown in Fig. 2. This model differs from the original model (Hirtenlehner et al., 2016) and its subsequent model (Mukai et al., 2019) in the following three aspects: (1) the present model incorporates sub-constructs of the fear of crime (social-level and individual-level fear of crime) and punitiveness (support for harsher punishment and criminalization); (2) it replaces authoritarian attitudes with SDO, which is assumed to consist of a general attitudinal orientation toward hierarchical inter-group relations (SDO-D) and toward equal inter-group relations (SDO-E) (Ho et al., 2012; Ho et al., 2015) ${ }^{3}$; and (3) it includes identity anxiety and assumes that this variable, in parallel with economic anxiety, consists of late modern anxieties in order to exert influence on SDO, xenophobic attitudes, fear of crime, and punitiveness.

\section{Research Methodology}

\section{Sampling}

Questionnaires were completed by 1000 Japanese respondents on May 1, 2020. A questionnaire was distributed to the company's monitors. These monitors include approximately 4.5 million Japanese aged older than fifteen. Monitors were recruited mainly through web advertisements. To be eligible, such monitors were first required to register their personal information (i.e., gender, age, place of residence, cell-phone number, e-mail address, etc.). Once they became eligible, they were able to browse the questionnaire posted on a web survey company's web page, and those who found it interesting enough to participate in the study completed it via their own device (i.e., cell-phone, personal computer, etc.). They received web credits that can be converted into cash or gift certificates upon their completion of the questionnaire.

Previous research typically utilizes age, gender, education, and income as controls (Costelloe et al., 2009; Falco \& Martin, 2012; Johnson, 2001; King \& Maruna, 2009). Among them, data regarding age and gender distribution are available from a highly reliable national census. Thus, to secure the validity or the representativeness of the sample, proportional

\footnotetext{
${ }^{3}$ For further discussion on the dimensionality of SDO, see Ho et al. (2012); Ho et al. (2015); Li et al. (2006); and Jost and Thompson (2000).
} 


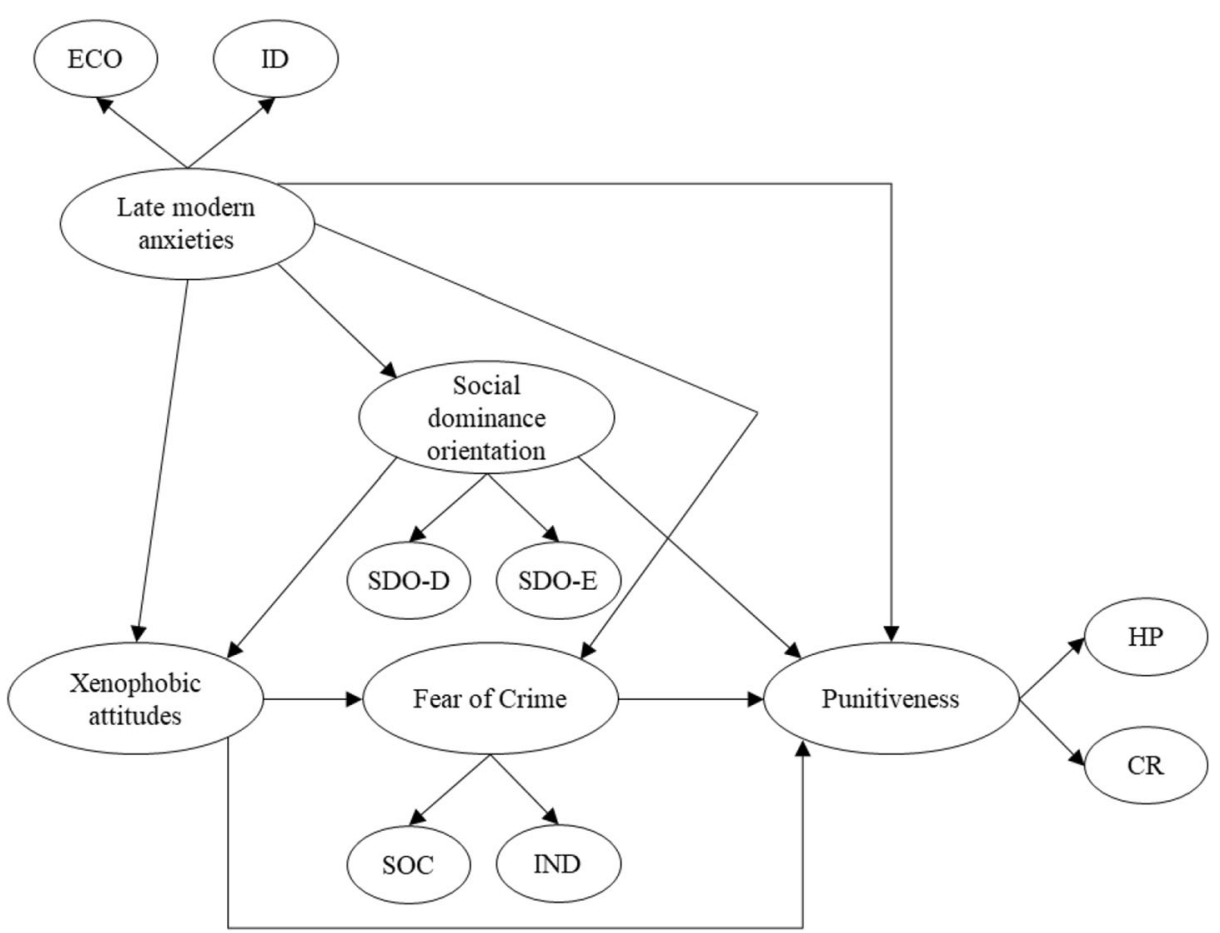

Fig. 2 Hypothetical model. ECO economic anxiety, $I D$ identity anxiety, $S D O-D$ dominance orientation, $S D O-E$ egalitarian orientation, $S O C$ social-level fear of crime, IND individual-level fear of crime, $H P$ support for harsher punishment, $C R$ support for criminalization

sampling was applied according to the population estimates of age and gender as of April 2020 (Ministry of Internal Affairs and Communications, 2020). Additionally, we included a trap question which stated, "Please choose 'disagree to some degree' for this item," and excluded 238 respondents who answered otherwise. This procedure resulted in a final sample size of 762 respondents.

\section{Variables}

The respondents' background characteristics of gender, age, and annual household income were available through data linked to each monitor. Females represented 55.2\% $(n=421)$ of the sample with males at $44.8 \%(n=341)$. Regarding their ages, $14.6 \%(n=111)$ of the sample were younger than $29 ; 43.6 \%(n=332)$ were between the ages of 30 and 59 ; and $41.9 \%(n=$ $319)$ were older than 60 . In terms of annual household income, $16.3 \%(n=124)$ of the sample had one lower than 1,999,999 yen; $40.3 \%(n=307)$ between 2,000,000 and 4,999,999 yen; $32.9 \%(n=251)$ between $5,000,000$ and 9,999,999 yen; and $10.5 \%(n=80)$ higher than $10,000,000$ yen.

All of the scales included in the questionnaire were rated on a Likert scale and were presented in Japanese. To secure the validity of the results, instead of translating the scales used in Hirtenlehner et al. (2016), we used the scales validated in a Japanese context. ${ }^{4}$ Since

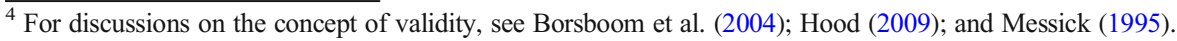


factor structure of all scales used in the analysis was confirmed in previous studies, we simply calculated their Cronbach's alpha to test their reliability. The calculation showed all scales have acceptable reliability (Cronbach's $\alpha \mathrm{s}>.81$ ). The SEM was conducted using R version 3.6.3 and lavaan package version 0.6-5 (Rosseel 2012); HAD version 16.0 (Shimizu 2016) was used for the other analyses.

\section{Punitiveness}

The scale of punitiveness was drawn from the attitudes toward the criminal justice scale (Mukai and Fujino 2018) (see Appendix A online for the questions in Japanese and their English translations). The scale included two distinct subscales: support for harsher punishment and support for criminalization. While the former subscale (five items) taps into respondents' support for more punitive measures such as longer sentencing (e.g., "Criminals should be punished harsher"), the latter subscale (six items) measures the support for criminalizing minor acts that are not punished by criminal justice (e.g., "The punishment should be inflicted at the time when someone has done an act which disturb someone else"). Respondents were asked to rate their attitude on a six-point Likert scale (completely disagree $=1$; completely agree $=6$ ).

\section{Fear of Crime}

This was measured by the emotional reactions toward the crime scale (Arai et al., 2010) (see Appendix B). This scale entails the social-level and the individual-level fear of crime. The former subscale was measured with three items such as "I am afraid of social security," and the latter measured with two items such as "I am afraid of being victimized." Respondents were asked to rate their feelings on a five-point Likert scale (completely disagree $=1$; completely agree $=5$ ).

\section{Xenophobic Attitudes}

The previous research (Mukai et al., 2019) used the anti-foreigner scale (Kim, 2015) to measure xenophobic attitudes. However, this scale was proven to have a low reliability $(\alpha=.65)$. Therefore, the present research used another scale developed by Tsuji and Kitamura (2018) to measure this construct (see Appendix C). Regarding "foreigners who came to Japan with the intention to settle," respondents were asked how much degree they agree or disagree with the following eight statements such as "Japanese culture is gradually being undermined by these foreigners" on a five-point Likert scale (disagree= 1 ; agree $=5$ ).

\section{Social Dominance Orientation}

This was measured with the 16-item $\mathrm{SDO}_{6}$ scale of Pratto et al. (2006) (see Appendix D), which was slightly modified from the one presented in Pratto et al. (1994). Eight items measured SDO-D (e.g., "Some groups of people are just more worthy than others"), and another eight measured SDO-E (e.g., "It would be good if all groups could be equal"). Respondents were asked to how much degree they agreed or disagreed with the items on a seven-point Likert scale (strongly disagree/oppose $=1$; strongly agree/favor $=7$ ). 


\section{Late Modern Anxieties}

This variable consisted of economic anxiety and identity anxiety. Regarding economic anxiety, respondents described how anxious they were about the following economic situation such as "taxes being raised in the future" and their "living standard lowering" (see Appendix E). The items were derived and translated from Hirtenlehner et al. (2016) and a five-point Likert scale was used (not anxious at all $=1$; very much anxious $=5$ ).

Identity anxiety is characterized by having an unstable identity and being anxious about having such an identity. The "Certainty of self" factor (10 items) identity achievement scale of Shimoyama (1986) was used to measure the variable. The construct of factor is "sense of reality and trust toward self and environment surrounding self" (Shimoyama, 1986, p. 24). Example items are, "I do not know who I am," and "I am not sure what kind of person I will be in the future" (see Appendix F). A four-point Likert scale was used (does not apply=1; applies $=4$ ).

\section{Results}

Table 1 shows the means $(M)$, standard deviations $(S D)$, alpha coefficients $(\alpha)$, and correlations of the scales discussed above. Punitiveness correlated to all the dependent variables except SDO's subscale-SDO-E $(r=.00, p=.90)$.

To estimate the fits (CFI and RMSEA) and the Bayesian information criterion (BIC) of the hypothetical model shown in Fig. 2, SEM was conducted using a maximum-likelihood estimation. The estimation yielded values of CFI $=.889$, RMSEA $=.048$, and $\mathrm{BIC}=$ 102,707.800. A CFI value of more than .90 and RMSEA value of less than .05 are considered to indicate a good model fit (Kline, 2010). The CFI value of the present model failed to satisfy this criterion. Therefore, referring to modification indices, we modified the model by setting two covariances between items in the xenophobic attitude scale. Specifically, we set covariances between the items "once these foreigners have lawfully immigrated, they should have equal rights as Japanese do" and "once these foreigners have lawfully immigrated, it would be better if they receive a compulsory education as Japanese do." We also set them in between "these foreigners, in general, are beneficial to the Japanese economy" and "such foreigners bring new ideas and cultures, making Japanese society better." Notably, in addition to setting covariance between these items which improves the model fit, it can be stated that these items are conceptually similar and these modifications are reasonable. The modified model yielded acceptable fits $(\mathrm{CFI}=.900$, RMSEA $=.046)$, and $\mathrm{BIC}$ was also slightly improved $(\mathrm{BIC}=$ 102,461.174). The final model is shown in Fig. 3.

The results showed that late modern anxieties consisted of identity anxiety and economic anxiety related positively to both $\operatorname{SDO}(\beta=.20, p<.01)$ and xenophobic attitudes $(\beta=.26$, $p<.01)$; moreover, the SDO, in turn, exerted influence on xenophobic attitudes $(\beta=.44$, $p<.01)$. Late modern anxieties was also highly related to fear of crime $(\beta=.83, p<.01)$, but its relation with punitiveness did not reach a significant level $(\beta=-.24, p=.18)$, probably due to a relatively great standard error of the path between late modern anxieties and punitiveness $(S . E .=.25)$. The relation between fear of crime and xenophobic attitudes also did not reach a significant level $(\beta=.09, p=07)$. Finally, punitiveness was significantly related with fear of crime $(\beta=.72, p<.01)$, xenophobic attitudes $(\beta=.24, p<.01)$, and $\operatorname{SDO}(\beta=.17$, $p<.01$ ). 


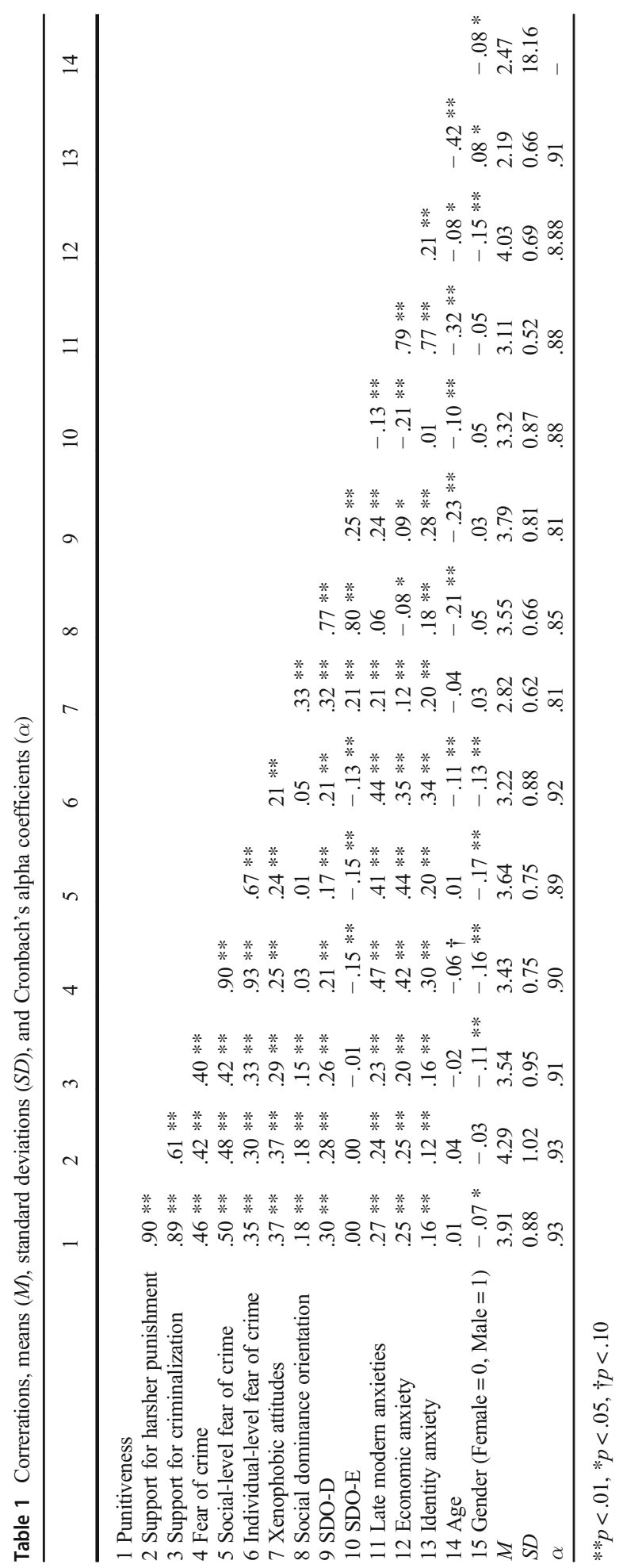




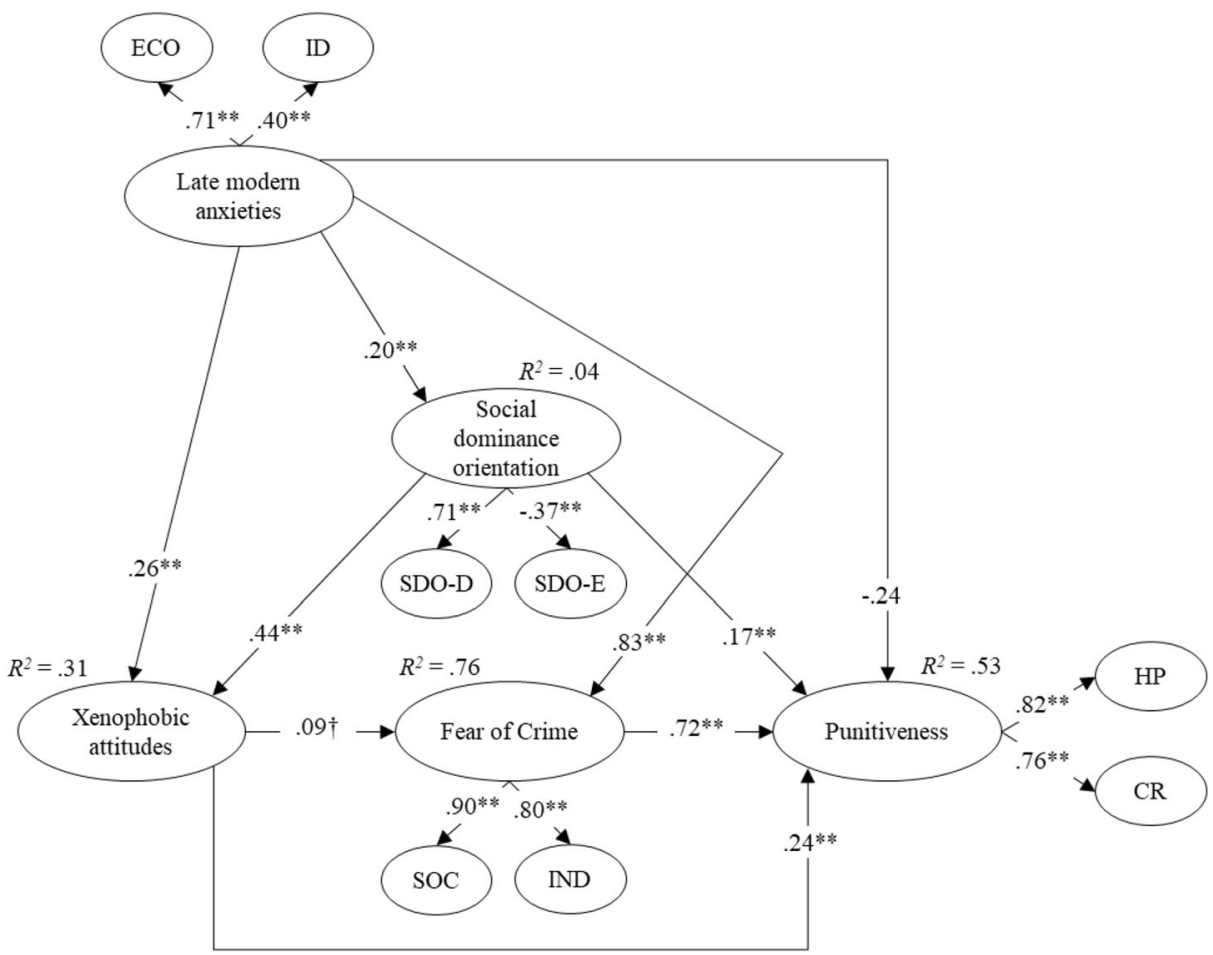

Fig. 3 Results of structural equations modeling (SEM). ECO economic anxiety, ID identity anxiety, SDO-D dominance orientation, $S D O-E$ egalitarian orientation, $S O C$ social-level fear of crime, IND individual-level fear of crime, $H P$ support for harsher punishment, $C R$ support for criminalization. Observed variables are not shown in the figure. $* * p<.01 ; \dagger p<.10$

To estimate the indirect and total effects of fear of crime, xenophobic attitudes, SDO, and late modern anxieties on punitiveness for the final model, we conducted a bootstrap mediation analysis utilizing 10,000 resamples. As shown in Fig. 3, although late modern anxieties did not exert a direct effect on punitiveness $(\beta=-.24, p=.18)$, it displayed a significant total effect via fear of crime, xenophobic attitudes, and SDO ( $\beta=.42,95 \%$ CI $[.45, .77])$, as shown in Table 2. The total effects of xenophobic attitudes and SDO were also significant (xenophobic

Table 2 Direct, indirect, and total effects of crime, xenophobic attitudes, social dominance orientation, and late modern anxieties on punitiveness

\begin{tabular}{|c|c|c|c|c|c|c|c|c|c|c|c|c|}
\hline & \multicolumn{4}{|c|}{ Direct effect } & \multicolumn{4}{|c|}{ Indirect effect } & \multicolumn{4}{|c|}{ Total effect } \\
\hline & $\beta$ & S.E. & $B$ & $95 \% \mathrm{CI}$ & $\beta$ & S.E. & $B$ & $95 \%$ CI & $\beta$ & S.E. & $B$ & $95 \% \mathrm{CI}$ \\
\hline Fear of crime & $.72 * *$ & .08 & .51 & {$[.27, .75]$} & & & $-^{\mathrm{a}}$ & & $.72 * *$ & .08 & .51 & {$[.27, .75]$} \\
\hline $\begin{array}{l}\text { Xenophobic } \\
\text { attitudes }\end{array}$ & $.24 * *$ & .07 & .29 & {$[.15, .42]$} & .06 & .05 & .08 & {$[-.01, .17]$} & $.30 * *$ & .08 & .36 & {$[.22, .51]$} \\
\hline $\begin{array}{l}\text { Social } \\
\text { dominance } \\
\text { orientation }\end{array}$ & $.17 * *$ & .09 & .24 & {$[.06, .42]$} & .03 & .02 & .04 & {$[-.01, .09]$} & $.20 * *$ & .10 & .28 & {$[.09, .47]$} \\
\hline $\begin{array}{l}\text { Late modern } \\
\text { anxiety }\end{array}$ & -.24 & .25 & -.34 & {$[-.84, .15]$} & $.65 * *$ & .23 & .95 & {$[.50,1.40]$} & $.42 * *$ & .08 & .61 & {$[.45, .77]$} \\
\hline
\end{tabular}

${ }^{\text {a }}$ Effect not examined. $* * p<.01, * p<.05$ 
attitudes: $\beta=.30,95 \%$ CI $[.22, .51]$; SDO: $\beta=.20,95 \%$ CI $[.09, .47])$; but, their indirect effects were markedly smaller than that of late modern anxieties and failed to reach a significant level (xenophobic attitudes: $\beta=.06,95 \%$ CI $[-.01, .17]$; SDO: $\beta=.03,95 \% \mathrm{CI}$ $[-.01, .09])$.

\section{Discussion}

The present study aimed to test the generalizability of the existing model (Hirtenlehner et al., 2016), which explains public punitiveness, basing on late modern perspective, to Japanese context, and then expanding its scope by introducing new variables into the model.

The argument of late modern perspective of punitiveness (Bauman, 2000, 2005; Young, 1999) suggests that criminals are utilized as scapegoats of abstract anxieties beyond an individual's control. Based on this argument, the current study constructed the hypothetical model which assumed that individuals support punitive measures on criminals to compensate for late modern anxieties that consist of economic anxiety and identity anxiety. This is a result of the late modernization of society, and these relationships are mediated by SDO, xenophobic attitudes, and the fear of crime. To test the validity of the hypothetical model, we conducted SEM using data from Japanese respondents recruited via a web survey company. The subsequent results showed the model fit the data well, lending support to the model.

Substantially, all previous empirical research that investigated individual punitiveness was conducted in Western societies (Roberts et al., 2003). In this sense, the generalizability of the perspective to other societies has not been tested - and thus, the utility of the perspective has remained unclear. However, the findings presented here indicate that the model constructed based on late modern perspective can be applied to a non-Western society-namely, Japan. This society, like industrialized Western societies, is experiencing the radical transformation of once-stable social establishments such as welfare and economic systems, families, communities, nationalities (via increased immigration), and evidently, the criminal justice system. Such similarities in social levels can be considered as the main basis of the model's generalizability.

Furthermore, this model provides insights into a widely accepted framework explaining punitiveness: instrumental and symbolic explanations (Hirtenlehner, 2010; Tyler and Boeckmann, 1997; Tyler \& Weber, 1982), though the terminology slightly differs among researchers (King \& Maruna, 2009). While instrumental theories suggest that punitiveness is the consequence of the public's desire to lower the crime rate, symbolic theories suggest that punitiveness is a socioeconomic response of crime rather than real threats of crime. Thus, on the one hand, the former theories predict that punitiveness relates factors concerning the prevention of crime such as the fear of crime. On the other hand, the latter theories predict that punitiveness relates more to abstract and broader "social attitudes" such as authoritarianism and conservatism. Categorizing our predictors in light of this distinction, the fear of crime can be classified as an instrumental factor and other factors (i.e., xenophobic attitudes, SDO, and late modern anxieties) as symbolic ones. Viewed in this way, our model can be considered as one that is incorporated with both instrumental and symbolic factors into a single model as well as one that elaborates their interrelations, with symbolic factors preceding instrumental ones. Accordingly, this model strongly suggests that the question which future research needs to address must not be one that asks, "Which factors relate with punitiveness, instrumental or symbolic ones?" but instead, "How do those factors relate together in order to relate with punitiveness?" 
Additionally, this model predicts that punitiveness strengthens in times of social turbulence. Japan, as well as many other countries, is now experiencing the COVID-19 pandemic and the resulting interruption of economic activities. In such circumstances, economic anxiety and xenophobic attitudes toward foreigners who are prone to be perceived as carriers of the virus are expected to be exacerbated; therefore, following the model's prediction, punitiveness is also likely to strengthen. Although testing whether this prediction would be supported by actual data evidently requires an analysis of longitudinal data, and thereby this study offers a warning to such a possibility.

Besides, the findings regarding the overall fit of the model as well as the four results from the individual paths merit discussion. First, a markedly high path coefficient $(\beta=.73)$ was observed between fear of crime and punitiveness. This significant relation is consistent with the model from Hirtenlehner et al. (2016), but it is inconsistent with Mukai et al. (2019). The inconsistency with Mukai et al. (2019) may be explained by the dimensions of fear of crime and punitiveness. Mukai et al. (2019) investigated the relationship between the individual level of fear of crime (i.e., fear that a respondent himself/herself feels about being victimized) and support for harsher punishments, which were found not to relate to each other in the previous study conducted in a Japanese context (Mukai \& Matsuki, 2020). In contrast, building on the previous research that suggested the multidimensionality of the fear of crime (Ferraro 1995) and punitiveness (Mukai and Fujino 2018), the current study incorporated the other dimensions of the fear of crime and punitiveness (i.e., social-level fear of crime and support for criminalization). This modification is likely to be the reason for the finding of a significant relation between fear of crime and punitiveness.

Second, the path coefficient between xenophobic attitudes and fear of crime was weak $(\beta=.09)$, thus failing to reach a significant level. This result is inconsistent with that of Hirtenlehner et al. (2016), but consistent with that of Mukai et al. (2019). One possible explanation of this discrepancy is that Japan is in a different situation concerning immigrants. As mentioned above, although the rise of xenophobia is also pointed out in Japan, as Japan has enforced policies and laws restricting immigration, the country remains not as diverse as Europe and the USA (Kingston, 2013). The number of foreign residents in Japan was estimated to be approximately 2.73 million at the end of 2019 (Ministry of Justice 2020), comprising approximately only $0.02 \%$ of its total population. Because of its small proportion, the salience of foreigners remains low, and consequently they are less linked to crime. Such characteristics of Japan may result in a failure to detect a significant relation between xenophobic attitudes and the fear of crime.

Yet, in 2018, Japan amended the Immigration Control and Refugee Recognition Act to direct its national policy toward accepting more foreign workers and immigrants to deal with the domestic shortage of the labor force. Considering such a policy shift, the number of immigrants is most likely to increase in the near future. Supporting this prediction, Japan's number of foreign residents is breaking historical records every year. Furthermore, against this backdrop, a xenophobic discourse that explicitly states the increased number of foreigners will cause higher crime rates appears to be attracting more supporters (Mihashi, 2017). Although our study did not detect a significant relation between xenophobic attitudes and fear of crime, this particular nexus needs to be cautiously monitored.

Third, our model assumed that identity anxiety, along with economic anxiety, comprises late modern anxieties. As expected, late modern anxieties exerted a significant positive effect on SDO $(\beta=.20)$, xenophobic attitudes $(\beta=.26)$, and fear of crime $(\beta=.83)$ - but not on punitiveness $(\beta=-.24)$. This finding is somewhat consistent with Hirtenlehner et al. (2016), 
which, incorporating only economic anxiety, showed that the variable did not have a direct effect on punitiveness. Notably, it might be possible to argue that, based on this finding, late modern anxieties are not important predictors of punitiveness itself. However, estimations of indirect and total effects showed that late modern anxieties have a significant total effect on punitiveness. Considering this result, even if late modern anxieties do not exert a direct effect on punitiveness, they need to be considered as underlying determinants that distally affect punitiveness.

Finally, our model incorporated SDO instead of authoritarian attitudes that was present in the original model of Hirtenlehner et al. (2016). This modification was done based on theoretical and empirical considerations. Theoretically, because the construct of authoritarian attitudes overlaps with that of punitiveness, such an overlap was expected to result in an insignificantly high relation. Empirically, previous research conducted mainly within a framework of the social dominance theory has repeatedly reported SDO positively related with punitiveness (Pratto et al., 1994), and consequently, SDO could play a role in determining punitiveness, as authoritarian attitudes did in the previous study. In fact, the results showed that SDO positively related punitiveness as well as xenophobic attitudes. So, taking the theoretical and empirical considerations together, when constructing a model explaining punitiveness, it is more desirable to incorporate SDO rather than authoritarian attitudes.

The findings presented in the current study clearly indicate that the model based on the late modern perspective may be a useful framework to explain punitiveness in Japan. However, the limitations of our study also imply that further work needs to be done. First, the present study attempted to maximize representativeness of sample and validity of responses by utilizing a proportional sampling technique and including a trap question. However, our respondents constituted a web survey company's monitors, and this might have limited the generalizability of the present findings to some degree. Specifically, as monitors were recruited by web advertisements and complete questionnaires via the Internet, they are expected to use the Internet more frequently than the general Japanese population. Previous research (Roche et al., 2016) indicates that those who were exposed to the Internet more frequently are less favorable to death penalty. Moreover, a study conducted in Japan shows that frequent Internet users tend to have more accurate information regarding situations of crime and punishment compared with those who are less frequent Internet users (Matsuki and Mukai in press). Considering these findings, our respondents might have shown a lower level of punitiveness compared with the entire Japanese population.

Additionally, unavailability of data on education distribution among monitors must be noted as a limitation of the present research. Existing literature has shown that, among background factors, education has a negative effect on punitiveness (Costelloe et al., 2009; Johnson, 2001; King \& Maruna, 2009). Although there is no compelling reason to believe that the monitors education distribution differs considerably from that of whole Japanese population, it is still possible that a potential effect of education might have influenced the present findings.

Second, although the present results suggest that the perspective can be a useful framework not only in Western societies but also in Japan, its further generalizability to the other societies (e.g., the other Asian societies) remains untested. It is pointed out that countries such as Korea (Choo 2017) and Taiwan (Li 2009) are experiencing social and judicial phenomena with which penal populism is often linked to-such as strengthened state punitiveness, increased presence of crime victims, and so on. These similarities possibly suggest the generalizability of the model might be applied to such industrialized Asian societies. Hence, conducting further 
research in those societies may be an interesting direction of future research. Relatedly, we used scales validated in the Japanese context to measure each construct instead of the translating scales used in Hirtenlehner et al. (2016). This was due to a consideration that to measure complex constructs such as xenophobic attitudes and punitiveness, it is essential to use scales validated in each context. Nevertheless, as a side effect, this has rendered it difficult to directly compare to the previous study (Hirtenlehner et al. 2016). Future research might need to use identical scales after checking their invariance.

Third, the present study focused on economic anxiety and identity anxiety as factors comprising late modern anxieties. Yet, anxieties stemming from late modernity are not limited to these factors (Garin, 2012; Hirtenlehner, 2006). For instance, King and Maruna (2009) pointed to "generational anxiety," or "worries about "kids today"” as predictors of punitiveness. Thus, further theoretical and empirical elaboration of the concept of late modern anxieties is necessary to fully understand the effects of social transformation reflected in an individual's mentality on punitiveness.

Fourth, while the present study has incorporated various factors into an integrated model, there are other variables related to punitiveness, which are compatible with the late modern perspective. Such variables include traditionalism (Garin, 2012), attribution (Falco \& Martin, 2012), and trust in politicians (Sööt, 2013), etc. Future research may wish to expand the present model by incorporating these variables into their model.

Supplementary Information The online version contains supplementary material available at https://doi.org/ 10.1007/s11417-020-09338-9.

Funding Information This work was supported by JSPS KAKENHI Grant Number JP19K13545.

Data Availability Online appendices are available.

\section{Compliance with Ethical Standards}

Conflict of Interest The authors declare that they have no conflict of interest.

Code Availability Not applicable.

\section{References}

Adorno, T. W., Frenkel-Brunswik, E., Levinson, D., \& Sanford, N. (1950). The authoritarian personality. New York: Harper.

Allison, A. (2013). Precarious Japan. Durham: Duke University Press.

Altemeyer, B. (1981). Right-wing authoritarianism. Winnipeg: University of Manitoba Press.

Altemeyer, B. (1998). The other "authoritarian personality." In M. P. Zanna (Ed.), Advances in experimental social psychology (Vol. 30, pp. 47-92). San Diego: Academic Press.

Arai, T., Fuji, K., \& Yoshida, F. (2010). The effects of information about crime on mother's anxiety about crime. Japanese Journal of Psychology, 81(4), 397-405 (in Japanese with English abstract).

Armborst, A. (2014). Kriminalitätsfurcht und punitive Einstellungen Indikatoren, Skalen und Interaktionen. Soziale Probleme, 25(1), 105-142.

Bauman, Z. (2000). Liquid modernity. Cambridge: Polity.

Bauman, Z. (2004). Identity: Conversation with Benedetto Vecchi. London: Polity. 
Bauman, Z. (2005). Work, consumerism and the new poor (2nd ed.). Philadelphia: Open University Press. Bauman, Z. (2008). The art of life. Cambridge: Polity.

Beck, U. (1986). Risikogesellschaft: Auf dem Weg in eine andere Moderne. Suhrkamp: Frankfurt am Main.

Borsboom, D., Mellenbergh, G. J., \& Van Heerden, J. (2004). The concept of validity. Psychological Review, 111(4), 1061-1071.

Bottoms, A. (1995). The philosophy and politics of punishment and sentencing. In C. Clarkson \& R. Morgan (Eds.), The politics of sentencing reform (pp. 35-60). Oxford: Clarendon.

Braithwaite, J. (1989). Crime, shame, and reintegration. Cambridge: University of Cambridge Press.

Choo, J. (2017). Critical review of punitiveness universality: Trends and issues in literatures. Korean Criminological Review, 28(2), 155-179 (in Korean with English abstract).

Costelloe, M. T., Chiricos, T., \& Gertz, M. (2009). Punitive attitudes toward criminals: Exploring the relevance of crime salience and economic insecurity. Punishment and Society, 11(1), 25-49.

ERD net (Japan NGO Network for the Elimination of Racial Discrimination). (2018). Joint civil society report on racial discrimination in Japan. https://imadr.org/wordpress/wp-content/uploads/2018/07/Revised_ERD-Net_ Joint-Civil-Society-Report_CERD96_2018.pdf. Accessed 28 May 2020.

Estévez-Abe, M. (2008). Welfare and capitalism in postwar Japan. New York: Cambridge University Press.

Falco, D. L., \& Martin, J. S. (2012). Examining punitiveness: Assessing views toward the punishment of offenders among criminology and non-criminology students. Journal of Criminal Justice Education, 23(2), 205-232.

Fenwick, M. (2013). 'Penal populism' and penological change in contemporary Japan. Theoretical Criminology, $17(2), 215-231$.

Ferraro, K. E. (1995). Fear of crime: Interpreting victimization risk. Albany: State University of New York.

Foote, D. H. (1992). The benevolent paternalism of Japanese criminal justice. California Law Review, 80, 317-390.

Garin, V. (2012). Social instability and reaction to deviance: A multilevel analysis of the Swiss lifelong detention initiative. Punishment and Society, 14(3), 289-314.

Garland, D. (2001). The culture of control. Chicago: University of Chicago Press.

Giddens, A. (1990). The consequences of modernity. California: Board of Trustees of the Leland Stanford Junior University.

Giddens, A. (1991). Modernity and self-identity: Self and society in the late modern era. London: Blackwell.

Hamai, K., \& Ellis, T. (2006). Crime and criminal justice in modern Japan: From re-integrative shaming to popular punitivism. International Journal of the Sociology of Law, 34(3), 157-178.

Hamai, K., \& Ellis, T. (2008). Japanese criminal justice: Was reintegrative shaming a chimera? Punishment and Society, $10(1), 25-46$.

Hara, J. (2007). Contemporary Japanese society and the new inequalities: A frontier of social stratification and inequality research. In Y. Sato (Ed.), Deciphering stratification and inequality: Japan and beyond (pp. 317). Melbourne: Trans Pacific Press.

Harvey, D. (2005). A brief history of neoliberalism. Oxford: Oxford University Press.

Hirtenlehner, H. (2006). Kriminalitätsfurcht: Ausdruck generalisierter ängste und schwindender gewissheiten? Untersuchung zur empirischen Bewährung der Generalisierungsthese in einer österreichischen Kommune. Kölner Zeitschrift Für Soziologie und Sozialpsychologie, 58(2), 307-331.

Hirtenlehner, H. (2010). Instrumentell oder expressiv? Zu den Bestimmungsfaktoren individueller Straflust. Soziale Probleme, 21(2), 192-224.

Hirtenlehner, H., Groß, E., \& Meinert, J. (2016). Fremdenfeindlichkeit, Straflust und Furcht vor Kriminalität: Interdependenzen im Zeitalter spätmoderner Unsicherheit. Soziale Probleme, 27(1), 17-47.

Ho, A. K., Sidanius, J., Pratto, F., Levin, S., Thomsen, L., Kteily, N., \& Sheehy-Skeffington, J. (2012). Social dominance orientation: Revisiting the structure and function of a variable predicting social and political attitudes. Personality and Social Psychology Bulletin, 38(5), 583-606.

Ho, A. K., Sidanius, J., Kteily, N., Sheehy-Skeffington, J., Pratto, F., Henkel, K. E., Foels, R., \& Stewart, A. L. (2015). The nature of social dominance orientation: Theorizing and measuring preferences for intergroup inequality using the new SDO7 scale. Journal of Personality and Social Psychology, 109(6), 1003-1028.

Hood, S. B. (2009). Validity in psychological testing and scientific realism. Theory and Psychology, 19(4), 451473.

Indermaur, D., \& Hough, M. (2002). Strategies for changing public attitudes to punishment. In J. Roberts \& M. Hough (Eds.), Changing attitudes to punishment: Public opinion, crime and justice (pp. 198-214). Cullompton: Willan.

Johnson, D. (2001). Punitive attitudes on crime: Economic insecurity, racial prejudice, or both? Sociological Focus, 34(1), 33-54.

Jost, J. T., \& Thompson, E. P. (2000). Group-based dominance and opposition to equality as independent predictors of self-esteem, ethnocentrism, and social policy attitudes among African Americans and European Americans. Journal of Experimental Social Psychology, 36(3), 209-232. 
Kim, M. (2015). Determinants of anti-foreigner sentiments in Japan: Using social attitude analysis as a framework. Kansai Sociological Review, 14, 36-53 (in Japanese with English abstract).

King, A., \& Maruna, S. (2009). Is a conservative just a liberal who has been mugged? Exploring the origins of punitive views. Punishment and Society, 11(2), 147-169.

Kingston, J. (2013). Contemporary Japan: History, politics, and social change since the 1980s. Oxford: WileyBlackwell.

Kline, R. B. (2010). Principles and practices of structural equation modeling (3rd ed.). New York: Guilford Press.

Kumakura, M., \& Kojima, D. (2018). Japan's inequality and redistribution: The perspectives of human capital and taxation/social insurance. Public Policy Review, 14(4), 663-690.

Lappi-Seppälä, T. (2012). Explaining national differences in the use of imprisonment. In S. Snacken \& E. Dumortier (Eds.), Resisting punitiveness in Europe? Welfare, human rights, and democracy (pp. 35-72). London: Routledge.

Li, J. (2009). Local punishment, global order [zaidi de xingfa, quanqiu de zhixu]. Taipei: Angle Publishing (in Chinese).

Li, Z., Wang, L., Shi, J., \& Shi, W. (2006). Support for exclusionism as an independent dimension of social dominance orientation in mainland China. Asian Journal of Social Psychology, 9(3), 203-209.

Maruna, S., \& King, A. (2009). Once a criminal, always a criminal?: "Redeemability" and the psychology of punitive public attitudes. European Journal on Criminal Policy and Research, 15(1-2), 7-24.

Matsuki, Y., \& Mukai, T. (in press). The relationship between perceived risk and knowledge about crime. Japanese Journal of Law and Psychology (in Japanese with English abstract).

McCormack, N., \& Kawabata, K. (2020). Inclusion and exclusion in neoliberalizing Japan. In Y. Shiobara, K. Kawabata, \& J. Matthews (Eds.), Cultural and social division in contemporary Japan: Rethinking discourses of inclusion and exclusion (pp. 24-49). London: Routledge.

Messick, S. (1995). Validity of psychological assessment: Validation of inferences from persons' responses and performances as scientific inquiry into score meaning. American Psychologist, 50(9), 741-749.

Mihashi, T. (2017). Fate of the world's 5th immigration country Japan: "Trilemma of immigration policy" will destroy freedom and security [Imaya sekai 5i "imin ukeire taikoku” nihon no matsuro: "Imin seisaku no torirenma" ga jiyu to anzen wo hakai suru]. Tokyo: Tokuma Shoten (in Japanese).

Ministry of Internal Affairs and Communications (2020). Population estimates by age (five-year groups) and sex - November 1, 2019 (final estimates), April 1, 2020 (Provisional estimates). https:/www.e-stat.go.jp/statsearch/file-download?statInfId=000031932926\&fileKind=0. Accessed 5 May 2020.

Ministry of Justice (2020). Regarding the number of foreign residents as of the end of 2019. [Heisei 30 nen matsu genzai ni okeru zairyu gaikokujin su ni tsuite]. http://www.moj.go.jp/nyuukokukanri/kouhou/ nyuukokukanri04_00081.html. Accessed 27 May 2020. (in Japanese).

Ministry of Justice (n.d.). White paper on crime in 2018. http://hakusyo1.moj.go.jp/en/67/nfm/mokuji.html. Accessed 28 May 2020.

Miyazawa, S. (2008). The politics of increasing punitiveness and the rising populism in Japanese criminal justice policy. Punishment and Society, 10(1), 47-77.

Mukai, T., \& Fujino, K. (2018). Development of attitudes towards criminal justice scale. Japanese Journal of Law and Psychology, 18(1), 86-98 (in Japanese with English abstract).

Mukai, T., \& Matsuki, Y. (2020). The relationship between punitiveness and emotional reactions toward criminals and victims: The roles of fear, anger, and empathy. Japanese Journal of Research on Emotions, 27(3), 95-103 (in Japanese with English abstract).

Mukai, T., Fukushima, Y., Iriyama, S., \& Aizawa, I. (2019). Modeling determinants of punitiveness: The roles of economic insecurity, fear of crime, and xenophobic attitudes. Ryukoku Corrections and Rehabilitation Center Journal, 9, 69-83 (in Japanese with English abstract).

Ousey, G. C., \& Unnever, J. D. (2012). Racial-ethnic threat, out-group intolerance, and support for punishing criminals: A cross-national study. Criminology, 50(3), 565-603.

Park, S. (2017). Inventing aliens: Immigration control, 'xenophobia' and racism in Japan. Race and Class, 58(3), 64-80.

Pratt, J. (2006). Penal populism. New York: Routledge.

Pratto, F., Sidanius, J., Stallworth, L. M., \& Malle, B. F. (1994). Social dominance orientation: A personality variable predicting social and political attitudes. Journal of Personality and Social Psychology, 67(4), 741763.

Pratto, F., Sidanius, J., \& Levin, S. (2006). Social dominance theory and the dynamics of intergroup relations: Taking stock and looking forward. European Review of Social Psychology, 17(1), 271-320.

Public Relations Office, Cabinet Office, The Government of Japan (2018). Overview of the public opinion survey on the life of the people. https://survey.gov-online.go.jp/h30/h30-life/summary.pdf. Accessed 19 May 2020. 
Putnam, R. D. (2000). Bowling alone: The collapse and revival of American community. New York: Simon and Schuster.

Roberts, J. V., \& Hough, M. (2005). Understanding public attitudes to criminal justice. Berkshire: Open University Press.

Roberts, J. V., Stalans, L. J., Indermaur, D., \& Hough, M. (2003). Penal populism and public opinion: Lessons from five countries. Oxford: Oxford University Press.

Roche, S. P., Pickett, J. T., \& Gertz, M. (2016). The scary world of online news? Internet news exposure and public attitudes toward crime and justice. Journal of Quantitative Criminology, 32(2), 215-236.

Rosseel, Y. (2012). Lavaan: An R package for structural equation modeling. Journal of Statistical Software, $48(2), 1-36$.

Shimizu, H. (2016). An introduction to the statistical free software HAD: Suggestions to improve teaching, learning and practice data analysis. Journal of Media, Information and Communication, 1, 59-73 (in Japanese with English abstract).

Shimoyama, H. (1986). A study on the vocational indecision of undergraduates. Japanese Journal of Educational Psychology, 34(1), 20-30 (in Japanese with English abstract).

Shiobara, Y. (2020). Introduction: Social division and exclusionism in contemporary Japan. In Y. Shiobara, K. Kawabata, \& J. Matthews (Eds.), Cultural and social division in contemporary Japan: Rethinking discourses of inclusion and exclusion (pp. 3-23). London: Routledge.

Sidanius, J., Liu, J. H., Shaw, J. S., \& Pratto, F. (1994). Social dominance orientation, hierarchy attenuators and hierarchy enhancers: Social dominance theory and the criminal justice system. Journal of Applied Social Psychology, 24(4), 338-366.

Sidanius, J., Mitchell, M., Haley, H., \& Navarrete, C. D. (2006). Support for harsh criminal sanctions and criminal justice beliefs: A social dominance perspective. Social Justice Research, 19(4), 433-449.

Simon, J. (2007). Governing through crime: How the war on crime transformed American democracy and created a culture of fear. Oxford: Oxford University Press.

Sööt, M. L. (2013). Trust and punitive attitudes. Crime, Law and Social Change, 59(5), 537-554.

Tanaka, T. (2019). Japanese welfare state in comparative perspective: An overview. Hitotsubashi Bulletin of Social Sciences, 11, 17-31.

The Nikkoso Research Foundation for Safe Society (2019). A survey research for fear of crime and other related subjects: The 6th research report [Hanzaini taisuru fuankan tou ni kansuru chousa kenkyu: Dai 6 kai chousa houkokusho]. https:/www.syaanken.or.jp/wp-content/uploads/2019/08/31041bouhan31_01.pdf. Accessed 17 December 2020.

Tsuji, D., \& Kitamura, S. (2018). Exposure to online news and polarization of xenophobic attitudes: A quantitative analysis of survey data in Japan and the U.S. Journal of Information and Communication Research, 36(2), 99-109 (in Japanese with English abstract).

Tyler, T. R., \& Boeckmann, R. J. (1997). Three strikes and you are out, but why? The psychology of public support for punishing rule breakers. Law and Society Review, 31(2), 237-265.

Tyler, T. R., \& Weber, R. (1982). Support for the death penalty: Instrumental response to crime, or symbolic attitude? Law and Society Review, 17(1), 21-44.

Uzuhashi, T. (2003). Japanese model of welfare state: How it was changed throughout "the lost decade" of the 1990's? Japanese Journal of Social Security Policy, 2(2), 1-11.

Young, J. (1999). The exclusive society: Social exclusion, crime and difference in late modernity. London: Sage.

Young, J. (2007). The vertigo of late modernity. London: Sage.

Young, J. (2010). Criminological imagination. Cambridge: Polity.

Publisher's Note Springer Nature remains neutral with regard to jurisdictional claims in published maps and institutional affiliations. 